\title{
Expression of c-Type Lysozyme from the Fleshy Shrimp Fenneropenaeus chinensis Is Upregulated Following Vibrio anguillarum and Lipopolysaccharide Injection
}

\author{
Guo Qiao, Su-Kyoung Kim, Yeong-Rok Cho, Sukyoung Kim and In-Kwon Jang* \\ West Sea Fisheries Research Institute, National Fisheries Research \& Development Institute, Incheon 400-420, Korea
}

\begin{abstract}
Chicken-type lysozyme (c-lysozyme) is present in shrimp and is active against some bacteria. To further understand the regulation of c-lysozyme in the fleshy shrimp Fenneropenaeus chinensis, we determined the tissue-specific gene expression of c-lysozyme and the time-course of mRNA expression in response to Vibrio anguillarum and lipopolysaccharide (LPS) injection by quantitative reverse real-time polymerase chain reaction. The results showed that c-lysozyme was expressed in all tissues tested, including gill, eyestalk, eye, hemocytes, hepatopancreas, intestine, heart, and pleopod. It was most highly expressed in the intestine followed by the eyestalk, gill, hemocytes and hepatopancreas. The mRNA expression level began to decline in a short time after $V$. anguillarum challenge and was then upregulated by two fold or more at $24 \mathrm{~h}$ post injection (hpi) compared to that at $0 \mathrm{~h}$. Expression was suppressed shortly after LPS injection and began to increase with higher levels of 5.8-, 5.2- and 8.4-fold at 24, 48, and $72 \mathrm{hpi}$, respectively. Higher expression was sustained and showed a gradual increasing trend until the end of the experiment (72 hpi). These results increase our understanding of the regulation of defense mechanisms and facilitate an evaluation of the effects of probiotics or immunostimulants in shrimp culture.
\end{abstract}

Key words: Fenneropenaeus chinenesis, c-type lysozyme, Quantitative real-time PCR (qRT-PCR), Vibrio anguillarum, Lipopolysaccharide (LPS)

\section{Introduction}

Like all invertebrates, the fleshy shrimp, Fenneropenaeus chinensis, is protected from pathogens by innate immunity due to the lack of adaptive immunity (Zasloff, 2002). Lysozymes and antibacterial peptides are the first line of defense to protect against bacterial infection in invertebrates, (Jollès and Jollès, 1984). Lysozymes (EC 3.2.1.17) are found within the semi-granular and granular hemocytes of many marine invertebrates and are released by a process of degranulation of hemocytes during the immune response (Ratcliffe et al., 1985; Sung and Sun, 1999). Lysozymes are glycoside hydrolases that catalyze cleavage of the $\beta-1,4$-glycosidic bond between
$\mathrm{N}$-acetyl glucosamine and $\mathrm{N}$-acetyl muramic acid in the peptidoglycans (PGs) of bacterial cell walls (Qasba and Kumar, 1997). Based on differences in structural, catalytic, and immunological characteristics, lysozymes are generally classified into six main types: chicken-type (Hultmark, 1996), goosetype (Prager and Jollès, 1996), invertebrate (Jollès and Jollès, 1975), T4 phage (Fastrez, 1996), bacterial (Holtje, 1996), and plant (Beintema and Terwisscha van Scheltinga, 1996), whereas immune (i-) and chicken (c-) lysozymes have been found in shrimp (Supungul et al., 2002, 2010). The i-lysozyme was initially described in starfish, Asterias rubens, by Jollès
http://dx.doi.org/10.5657/FAS.2013.0267

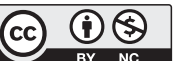

This is an Open Access article distributed under the terms of the Creative Commons Attribution Non-Commercial Licens (http://creativecommons.org/licenses/by-nc/3.0/) which permits unrestricted non-commercial use, distribution, and reproduction in any medium, provided the original work is properly cited.
Received 24 December 2012; Revised 31 July 2013

Accepted 01 August 2013

*Corresponding Author

E-mail: jangik@korea.kr 
and Jollès (1975). Subsequently, it has been reported in crustaceans and decapods, which show strong antimicrobial activity against Gram-positive and Gram-negative bacteria (Paskewitz et al., 2008; Supungul et al., 2010; Zhang et al., 2010). The i-lysozyme is expressed in multiple tissues and organs, and expression level increases following a bacterial challenge (dela-Re-Vega et al., 2006; Supungul et al., 2010; Zhang et al., 2010). In contrast, i-lysozyme shows high activity in bivalve digestive tissues, and associated species have the ability to use bacteria as a nutrient source (McHenery et al., 1979; Dobson et al., 1984), suggesting that i-lysozyme may function as a digestive enzyme in organisms such as the eastern oyster, Crassostrea virgincia (Xue et al., 2010). Invertebrates may produce different lysozymes for immunity (Peregrino-Uriarte et al., 2012) and digestion (Dobson et al., 1984; Supungul et al., 2010), and the digestive i-lysozyme could have evolved from immune lysozymes via positive selection (Supungul et al., 2010). The c-lysozyme is the most often found group in various organisms, including viruses, bacteria, plants, insects, reptiles, birds, fish, crustaceans, and mammals (Mai and $\mathrm{Hu}$, 2009). In crustaceans, it has been identified in white shrimp, Litopenaeus vannamei (Sotelo-Mundo et al., 2003), Kuruma prawn, Marsupenaeus japonicus (Hikima et al., 2003), F. chinensis (Bu et al, 2008), giant tiger shrimp, Penaeus monodon (Supungul et al., 2002; Tyagi et al., 2007), banana shrimp, F. merguiensis (Mai and Hu, 2009), swimming crab, Portunus trituberculatus (Pan et al., 2010), and Pacific blue shrimp, $L$. stylirostris (de Lorgeril et al., 2005; Mai and Hu, 2009). The c-lysozyme from $F$. chinensis had been cloned and the fulllength cDNA sequence (709 bp) has been determined (Bu et al., 2008). An open reading frame of $477 \mathrm{bp}$ is present with 159 encoded amino acids. The predicted protein has a signal peptide, and the theoretical molecular weight of the mature protein is $16.2 \mathrm{kD}$. The recombinant protein (colonially expressed into Escherichia coli BL21) shows high antibacterial activity against some Gram-positive bacteria, and has a lower minimal inhibition concentration against Gram-negative bacteria (Bu et al., 2008). However, little information is available on the time-course of the c-lysozyme mRNA transcript level against bacterial infection and tissue-specific expression. Therefore, we designed a real-time probe to detect the tissuespecific distribution to attain a better understanding of c-lysozyme function and its expression level against the pathogen
Vibrio anguillarum. The immunostimulant lipopolysaccharide (LPS) was also investigated to provide new insight into disease control in F. chinensis aquaculture.

\section{Materials and Methods}

\section{Primers and probe design for quantitative real- time reverse-transcription polymerase chain re- action (qRT-PCR)}

The cDNA sequence (GenBank accession no. AY661543) of the c-lysozyme from $F$. chinensis was retrieved from the NCBI database. A pair of gene-specific primers c-lyz-F, c-lyz$\mathrm{R}$ and the Taqman probe c-lyz-P were designed from the fulllength c-lysozyme cDNA sequence using the PrimerExpress software (Applied Biosystems Pty Ltd., Melbourne, Australia) (Table 1).

\section{Tissue-specific gene expression by qRT-PCR}

Total RNAs from eight tissues, including gill, eyestalk, eye, hemocytes, hepatopancreas, intestine, heart, and pleopod were prepared to determine the c-lysozyme expression sites in $F$. chinensis, and Taqman probe-based qRT-PCR was carried out to determine the relative transcription levels using the shrimp $\beta$-actin gene as an internal control. Seven tissues, except hemocytes, were obtained by dissection and stored in $200 \mu \mathrm{L}$ of RNA Later reagent (Ambion, Austin, TX, USA). Hemocytes were prepared as described by Jang et al. (2011). Briefly, hemolymph was collected from the ventral hemolymph sinus of F. chinensis (average body weight, $2.0 \mathrm{~g}$ ) with a 1-mL RNasefree syringe containing ice pre-cooled anticoagulant $(113 \mathrm{mM}$ glucose, $27.2 \mathrm{mM}$ sodium citrate, $2.8 \mathrm{mM}$ citric acid, and 71.9 $\mathrm{mM} \mathrm{NaCl}$ ). The hemocyte pellet was collected by centrifugation at $700 \mathrm{~g}$ and $4^{\circ} \mathrm{C}$ for $10 \mathrm{~min}$ and diluted with $200 \mu \mathrm{L}$ of RNA Later reagent. Total RNA was extracted from each tissue using the RNeasy Mini kit (Qiagen, Valencia, CA, USA) and further purified with DNase I (Qiagen) according to the manufacturer's protocol. First-strand cDNA was synthesized with the Prime-script First-strand cDNA Synthesis kit (Takara Bio, Shiga, Japan) using the oligo dT primer, according to the manufacturer's protocol. The synthesized cDNA was stored

Table 1. Primers and probes used in this study

\begin{tabular}{lll}
\hline Name & Nucleotide sequence $\left(\mathbf{5}^{\prime} \rightarrow \mathbf{3}^{\prime}\right)$ & Note \\
\hline c-lys-F & GGATCCCATGTTCCGATCTG & qRT-PCR c-lysozyme forward primer \\
c-lys-R & GGTTTCACGGCGGACAGT & qRT-PCR c-lysozyme reverse primer \\
c-lys-P & CGTCTGATGATATCACGGCTGCCCTG & qRT-PCR c-lysozyme probe \\
$\beta$-act-F & CCGAGCGTGGCTACACCTT & qRT-PCR $\beta$-actin forward primer \\
$\beta$-act-R & GCACAGCTTCTCCTTGATGTCA & qRT-PCR $\beta$-actin reverse primer \\
$\beta$-act-P & CCACCGCCGAGCGAGAAATCG & qRT-PCR \\
\hline
\end{tabular}


at $-80^{\circ} \mathrm{C}$ for later mRNA expression analysis. The qRT-PCR technique was used to assess the c-lysozyme transcription level using c-lyz-F, c-lyz-R, and Taqman c-lyz-P probe primers (Table 1). The qRT-PCR was conducted using the Onestep PrimeScript RT-PCR kit (Takara Bio). The final reaction volume was $20 \mu \mathrm{L}$, including $10 \mu \mathrm{L}$ of $2 \times$ One-step RT-PCR Buffer III, 2 units of Takara Ex Hot Start Taq enzyme, $0.4 \mu \mathrm{L}$ of Reverse Transcript Enzyme Mix II, and $0.4 \mu \mathrm{M}$ of each primer. The PCR was conducted as follows: $42^{\circ} \mathrm{C}$ for $5 \mathrm{~min}$, $95^{\circ} \mathrm{C}$ for $10 \mathrm{~s}$, followed by 40 cycles of $95^{\circ} \mathrm{C}$ for $5 \mathrm{~s}$ and $60^{\circ} \mathrm{C}$ for $30 \mathrm{~s}$. Fluorescent signal detection was initiated at the annealing stage during the first cycle. The comparative threshold cycle (CT) method ( $2^{-\Delta \Delta C T}$ method) was used to calculate relative expression (Livak and Schmittgen, 2001). The relative expression levels among the CT values of the target gene, clysozyme, and the $\beta$-actin housekeeping gene were compared by the $2^{-\triangle \Delta C T}$ method.

\section{Immune challenge by V. anguillarum and LPS}

\section{Shrimp maintenance}

Normal F. chinensis $(1.2 \pm 0.2 \mathrm{~g}$, mean \pm standard deviation [SD]) were obtained from the Taean Center at the West Sea Fisheries Research Institute, National Fisheries Research and Development Institute (NFRDI), Korea and maintained in static aquaria at a water temperature of $24-25^{\circ} \mathrm{C}$ in 30 practical salinity units at a $\mathrm{pH}$ of 7.8-8.2 for 2 weeks prior to the experiments. The shrimp were fed four times daily with a commercial diet (CJ Feeding Co., Seoul, Korea) and 50\% of the water was exchanged daily throughout the experimental duration. The feeding ration was $3 \%$ of mean body weight per day based on the feed conversion ratio.

\section{V. anguillarum challenge test}

$V$. anguillarum $\mathrm{KCTC} 2711$ was preserved at $-80^{\circ} \mathrm{C}$ in tryptic soy broth (TSB) supplemented with a final concentration of $2 \% \mathrm{NaCl}$ and $10 \%$ glycerol at NFRDI. The strain was routinely grown in TSB or tryptic soy agar supplemented with $2 \%$ $\mathrm{NaCl}$ at $27^{\circ} \mathrm{C}$ for $24 \mathrm{~h}$ prior to experiments. The V. anguillarum challenge tests were conducted in vivo as described by Qiao et al. (2012). In brief, bacterial suspensions were prepared by culturing the strain in TSB at $27^{\circ} \mathrm{C}$ for $24 \mathrm{~h}$, followed by washing and then adjusting the concentration to $10^{6}$ colony-forming units/mL (CFU/mL) with sterilized physiological saline (PS). The shrimp in the challenge groups were injected in the coxes of the third pair of pereiopods with a $0.02-\mathrm{mL}$ suspension of V. anguillarum $\left(10^{6} \mathrm{CFU} / \mathrm{mL}\right)$ using a $0.3-\mathrm{mL}$ insulin syringe (lot, 1234226; Becton Dickinson, Fullerton, CA, USA), and the control group was inoculated with an equal volume of PS. Each group included 70 individuals, and the experiments were conducted in triplicate.

\section{LPS immune stimulation}

LPS (integral component of the external membrane of the cell wall of Gram-negative bacteria Escherichia coli serotype O111:B4; Sigma Chemical Co. St. Louis, MO, USA) was stored at $4{ }^{\circ} \mathrm{C}$, and the working solution $(2.4 \mathrm{mg} / \mathrm{mL})$ (Rodríguez-Ramos et al., 2008) was dissolved in sterilized shrimp saline $(450 \mathrm{mM} \mathrm{NaCl})$. The challenge tests were conducted as described by Rodríguez-Ramos et al. (2008). Briefly, all shrimp in the stimulation group were injected with $0.02 \mathrm{~mL}$ of LPS suspension in the coxes of the third pair of pereiopods using a $100-\mu \mathrm{L}$ Hamilton syringe containing shrimp saline solution as the diluent. The control group was injected with the same volume of saline solution. Each group included 70 individuals, and the experiments were conducted in triplicate.

Temporal expression of c-lysozyme in response to $V$. anguillarum and LPS injection

Five individuals were sampled at each time point $(0,1,3$, $6,12,24,48$, and $72 \mathrm{~h}$ post injection [hpi]) from the above groups. Total RNA was isolated from the whole body, the cDNA was synthesized, and mRNA expression levels were determined as described above.

\section{Statistical analysis}

All samples were run in triplicate, and data are expressed as means \pm SD. Significant differences compared to the baseline (time $=0$ hpi) of each group were determined by Dunnett's $t$ test and significant differences among treatments at each time point were analyzed by Tukey's range test using the SPSS version 13.0 (SPSS, Inc., Chicago, IL, USA).

\section{Results}

\section{Tissue-specific gene expression of c-lysozyme}

The qRT-PCR results showed that the c-lysozyme transcript was detected in all tissues tested, including gill, eyestalk, eye, hemocytes, hepatopancreas, intestine, heart, and pleopod. It was most highly expressed in the intestine, followed by the eyestalk, gill, hemocytes, and hepatopancreas. The transcript level in the intestine was 1.65-, 1.49-, 2.76-, and 2.46-fold higher than that in the gill, eyestalk, hepatopancreas, and hemocytes, respectively (Fig. 1).

\section{Temporary expression of c-lysozyme in response to $V$. anguillarum injection}

The mRNA expression of c-lysozyme in the entire body of PS-control group shrimp was upregulated 4.25 -fold at 1 hpi and then began to recover (Fig. 2). The mRNA level began to decline in a short time post-challenge in the $V$. anguillarum challenge group and was then upregulated from 24 hpi until the end of the experiment ( $72 \mathrm{hpi}$ ). The transcription level was enhanced by about two fold compared to that at $0 \mathrm{~h}$ (Fig. 2). 


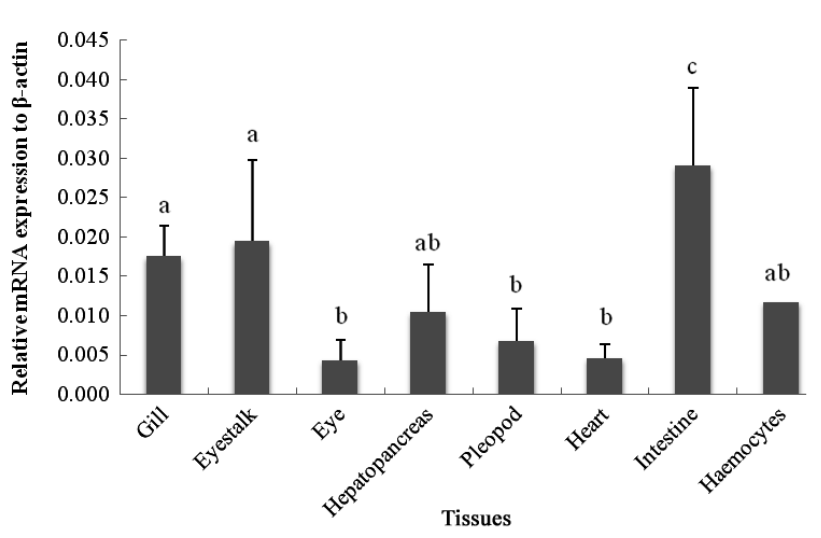

Fig. 1. Tissue-specific expression of c-lysozyme gene in fleshy shrimp Fenneropenaeus chinensis. The quantitative real-time reverse-transcription polymerase chain reaction was used to detect the mRNA expression and $\beta$-actin was amplified as a positive control. The results are showed with the mean of relative expression to $\beta$-actin \pm SD. The significant differences between tissues are indicated with the different letters.

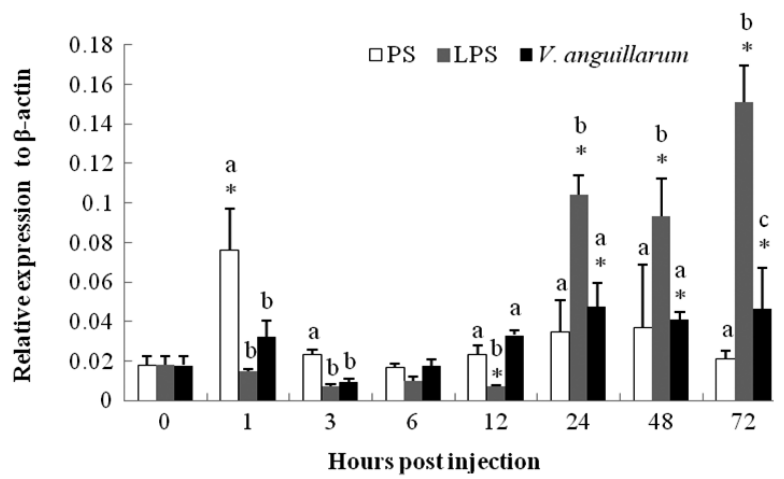

Fig. 2. Time-course mRNA expression of the c-lysozyme in the whole body of fleshy shrimp Fenneropenaeus chinensis after injected with physiological saline (PS), lipopolysaccharides (LPS) and Vibrio anguillarum. The quantitative real-time reverse-transcription polymerase chain reaction was used to detect the expression and $\beta$-actin was amplified as a positive control. The results are showed with the mean \pm SD. The significant differences compared to the baseline (time $=0 \mathrm{hpi}$ ) for each group are indicated with the asterisks. And the differences between treatments at each time point are marked with different letters.

\section{Temporary expression of c-lysozyme in response to LPS injection}

The c-lysozyme mRNA level was suppressed in a short time after the LPS injection, but began to increase $24 \mathrm{hpi}$. The expression level was 5.8-, 5.2-, and 8.4-fold at 24, 48, and 72 hpi, respectively, compared with that at $0 \mathrm{~h}$. Higher expression was sustained and showed a gradual increasing trend until the end of the experiment.

\section{Discussion}

The innate immune system represents the first barrier against pathogen infections in fish and shrimp (Zasloff, 2002). The c-lysozyme is an important member of this first line of defense against pathogenic bacteria. This enzyme exhibits lytic activity against a wide range of Gram-positive and -negative bacteria (Paskewitz et al., 2008; Supungul et al., 2010; Zhang et al., 2010). Hence, characterizing the c-lysozyme-encoding gene and its regulation by pathogens or immunostimulants is important for improvement of disease management strategies in aquaculture. Bu et al. (2008) cloned c-lysozyme from $F$. chinensis, and its characteristics were analyzed by bioinformatics. The purified recombinant c-lysozyme shows higher antibacterial activity against Gram-positive bacteria and relatively lower activity against Gram-negative bacteria in vitro, based on the minimum inhibitory concentration ( $\mathrm{Bu}$ et al., 2008). However, no more information is available on this gene tissue-specific distribution detected by qRT-PCR (probe) and the time-course of gene mRNA expression associated with pathogenic or immunostimulant induction in vivo. Therefore, to further understand the important role of this gene in immunity, we designed a pair of primers and a probe for qRTPCR to detect mRNA expression in various tissues and under different stimulation conditions. The results demonstrated that the c-lysozyme transcript was detected in all tissues tested, which agreed with the tissue distribution in P. monodon and L. vannamei (Burge et al., 2007; Tyagi et al., 2007; Supungul et al., 2010). c-lysozyme from $F$. chinensis was most highly expressed in the intestine, followed by the eyestalk, gill, hemocytes, and hepatopancreas, which was different from the patterns in P. monodon, L. vannamei, and L. stylirostris. The c-lysozyme in these species was particularly abundant in hemocytes followed by the intestine (de Lorgeril et al., 2005; Burge et al., 2007; Tyagi et al., 2007; Supungul et al., 2010). This tissue-specific distribution may be related to the species, developmental stage, or size of shrimp used in the various experiments. c-Lysozyme plays a role in the digestive systems of P. monodon, L. vannamei, and L. stylirostris (de Lorgeril et al., 2005; Burge et al., 2007; Tyagi et al., 2007; Supungul et al., 2010) based on its isopeptidase and chitinase activities (McHenery et al., 1979; Dobson et al., 1984; Supungul et al., 2010; Xue et al., 2010). These findings suggest that the high mRNA level in the $F$. chinensis intestine may be related to digestive function.

$V$. anguillarum is a prevalent pathogenic bacterium that affects commercial $F$. chinensis production (Yao et al., 2008). Unlike $V$. harveyi, little information is available on the immune response of shrimp against $V$. anguillarum infection. Therefore, we investigated the time-course c-lysozyme mRNA level to evaluate the effects of $V$. anguillarum and LPS on shrimp immunity. The c-lysozyme mRNA level in shrimp infected with $V$. anguillarum was downregulated for a short time and then upregulated at $24 \mathrm{~h}$ after $V$. anguillarum injection. Yao 
et al. (2008) investigated the lysozyme-like activity in $F$. chinensis after injection with $V$. anguillarum, and found that the activity increased significantly in hemocytes, which agreed with the results of several studies of lysozyme-like activity in shrimp (Burge et al., 2007; Zhao et al., 2007). However, those studies lacked detailed information about lysozyme types and the related mRNA levels associated with lysozyme-like activity. In other words, it is difficult to say which lysozyme genes modulate this lysozyme-like activity due to the various types of lysozymes. Upregulation of c-lysozyme mRNA expression at $24 \mathrm{hpi}$ was in agreement with results reported for $L$. vanna$m e i$ whose c-lysozyme has antibacterial activity against $V$. alginolyticus, $V$. parahaemolyticus, and $V$. cholerae (de-la-ReVega et al., 2006). Similar results were reported in the swamp crayfish, P. clarkii (Zhang et al., 2010), and in P. monodon hemocytes after 6,12 , and 24 hpi as a response to bacterial challenge (Supungul et al., 2010). These results suggest that the c-lysozyme from F. chinensis is involved in the innate immune system as well as in the digestive system.

The time-course of the mRNA level after $V$. anguillarum infection demonstrated that c-lysozyme has antibacterial activity. The biochemical mechanism of this activity is elusive, as it is possible that shrimp c-lysozyme enzymatically attacks LPS or the enzyme may be located in the periplasmic space where it can degrade PG, its natural substrate (de-la-Re-Vega et al., 2006). Gram-negative bacteria such as Vibrio sp. contain LPS in the cell wall and PGs in the periplasmic space (PeregrinoUriarte et al., 2012). Therefore, the c-lysozyme mRNA level was investigated after LPS injection. The results showed that c-lysozyme expression levels decreased by 0.3 -fold at 3 hpi, then increased by 8 - and 21 -fold at 72 hpi compared to at 0 and $3 \mathrm{hpi}$, respectively. These changes are in agreement with the results observed in the fat body of the army worm, Spodoptera exigua, after LPS injection (Bae and Kim, 2003). This result is also in accordance with reports of moderately increased lysozyme-like activity in the hemocytes of F. chinensis after laminarin injection (Yao et al., 2008). Similarly, the expression of c-lysozyme increases in P. monodon and $L$. vannamei after laminarin, LPS, and poly I: C stimulation ( $\mathrm{Ji}$ et al., 2009; Peregrino-Uriarte et al., 2012). These results suggest that c-lysozyme expression level in F. chinensis was enhanced after LPS stimulation. These findings will facilitate the development of effective approaches for disease prevention, such as use of immunostimulants, including LPS. Moreover, further studies of i-lysozyme from $F$. chinensis are required to elucidate its mechanism of action. The type of lysozyme (c- or i-lysozyme) that plays the more important role in the immune response and digestive system will be elucidated in future studies.

\section{Acknowledgements}

This work was supported by the Project "Environmental- friendly Aquaculture Technology using BFT (Biofloc Technology)" (RP-2012-AQ-128), National Fisheries Research \& Development Institute (NFRDI), Republic of Korea.

\section{References}

Bae S and Kim Y. 2003. Lysozyme of the beet armyworm, Spodoptera exigua: activity induction and cDNA structure. Comp Biochem Physiol B Biochem Mol Biol 135, 511-519. http://dx.doi. org/10.1016/S1096-4959(03)00119-2.

Beintema JJ and Terwisscha van Scheltinga AC. 1996. Plant lysozymes. In: Lysozymes: Model Enzymes in Biochemistry and Biology. Jollès $P$, ed. Birkhäuser Verlag, Basel, pp. 75-86.

Bu X, Du X, Zhou W, Zhao X and Wang J. 2008. Molecular cloning, recombinant expression, and characterization of lysozyme from Chinese shrimp Fenneropenaeus chinensis. Chin J Biotechnol 24, 723-732. http://dx.doi.org/10.1016/S1872-2075(08)60037-0.

Burge EJ, Madigan DJ, Burnett LE and Burnett KG. 2007. Lysozyme gene expression by haemocytes of Pacific white shrimp, Litopenaeus vannamei, after injection with Vibrio. Fish Shellfish Immunol 22, 327-339. http://dx.doi.org/10.1016/j.fsi.2006.06.004.

De Lorgeril J, Saulnier D, Janech MG, Gueguen Y and Bachère E. 2005. Identification of genes that are differentially expressed in haemocytes of the Pacific blue shrimp (Litopenaeus stylirostris) surviving an infection with Vibrio penaeicida. Physiol Genomics 21, 174183. http://dx.doi.org/10.1152/physiolgenomics.00281.2004.

De-la-Re-Vega E, García-Galaz A, Díaz-Cinco ME and Sotelo-Mundo RR. 2006. White shrimp (Litopenaeus vannamei) recombinant lysozyme has antibacterial activity against Gram negative bacteria: Vibrio alginolyticus, Vibrio parahemolyticus and Vibrio cholerae. Fish Shellfish Immunol 20, 405-408. http://dx.doi.org/10.1016/j. fsi.2005.06.005.

Dobson DE, Prager EM and Wilson AC. 1984. Stomach lysozymes of ruminants: I. distribution and catalytic properties. J Biol Chem 259, 11607-11616.

Fastrez J. 1996. Phage lysozymes. In: Lysozymes: Model Enzymes in Biochemistry and Biology. Jollès P, ed. Birkhäuser Verlag, Basel, pp. 35-64.

Hikima S, Hikima J, Rojtinnakorn J, Hirono I and Aoki T. 2003. Characterization and function of Kuruma shrimp lysozyme possessing lytic activity against Vibrio species. Gene 316, 187-195. http:// dx.doi.org/10.1016/S0378-1119(03)00761-3.

Holtje JV. 1996. Bacterial lysozymes. In: Lysozymes: Model Enzymes in Biochemistry and Biology. Jollès P, ed. Birkhäuser Verlag, Basel, pp. 65-74.

Hultmark D. 1996. Insect lysozymes. In: Lysozymes: Model Enzymes in Biochemistry and Biology. Jollès P, ed. Basel: Birkhäuser Verlag. pp. 87-102.

Jang IK, Pang Z, Yu J, Kim SK, Seo HC and Cho YR. 2011. Selectively enhanced expression of prophenoloxidase activating enzyme 1 (PPAE1) at a bacteria clearance site in the white shrimp, Litopenaeus vannamei. BMC Immunology 12, 70.

Ji PF, Yao CL and Wang ZY. 2009. Immune response and gene ex- 
pression in shrimp (Litopenaeus vannamei) haemocytes and hepatopancreas against some pathogen-associated molecular patterns. Fish Shellfish Immunol 27, 563-570. http://dx.doi.org/10.1016/j. fsi.2009.08.001.

Jollès J and Jollès P. 1975. The lysozyme from Asterias rubens. Eur J Biochem 54, 19-23. http://dx.doi.org/10.1111/j.1432-1033.1975. tb04108.x.

Jollès P and Jollès J. 1984. What's new in lysozyme research? Always a model system, today as yesterday. Mol Cell Biochem 63, 165-189.

Livak KJ and Schmittgen TD. 2001. Analysis of relative gene expression data using real-time quantitative PCR and the $2^{-\Delta \Delta \mathrm{Ct}}$ method. Methods 25, 402-408. http://dx.doi.org/10.1006/meth.2001.1262.

Mai WJ and Hu CQ. 2009. Molecular cloning, characterization, expression and antibacterial analysis of a lysozyme homologue from Fenneropenaeus merguiensis. Mol Biol Rep 36, 1587-1595. http:// dx.doi.org/10.1007/s11033-008-9355-8.

McHenery JG, Birkbeck TH and Allen JA. 1979. The occurrence of lysozyme in marine bivalves. Comp Biochem Physiol 63, 25-28. http://dx.doi.org/10.1016/0305-0491(79)90228-1.

Pan L, Yue F, Miao J, Zhang L and Li J. 2010. Molecular cloning and characterization of a novel c-type lysozyme gene in swimming crab Portunus trituberculatus. Fish Shellfish Immunol 29, 286292. http://dx.doi.org/10.1016/j.fsi.2010.04.011.

Paskewitz SM, Li B and Kajla MK. 2008. Cloning and molecular characterization of two invertebrate-type lysozymes from Anopheles gambiae. Insect Mol Biol 17, 217-225. http://dx.doi.org/10.1111/ j.1365-2583.2008.00797.x.

Peregrino-Uriarte AB, Muhlia-Almazan AT, Arvizu-Flores AA, Gomez-Anduro G, Gollas-Galvan T, Yepiz-Plascencia G and Sotelo-Mundo R. 2012. Shrimp invertebrate lysozyme $i$-lyz: gene structure, molecular model and response of $c$ and $i$ lysozymes to lipopolysaccharide (LPS). Fish Shellfish Immunol 32, 230-236. http://dx.doi.org/10.1016/j.fsi.2011.10.026.

Prager EM and Jollès P. 1996. Animal lysozymes c and g: an overview. In: Lysozymes: Model Enzymes in Biochemistry and Biology. Jollès $P$, ed. Birkhäuser Verlag, Basel, pp. 9-31.

Qasba PK and Kumar S. 1997. Molecular divergence of lysozymes and alpha-lactalbumin. Crit Rev Biochem Mol Biol 32, 255-306. http:// dx.doi.org/10.3109/10409239709082574.

Qiao G, Lee DC, Woo SH, Li H, Xu DH and Park SI. 2012. Microbiological characteristics of Vibrio scophthalmi isolates from diseased olive flounder Paralichthys olivaceus. Fish Sci 78, 853-863. http:// dx.doi.org/10.1007/s12562-012-0502-8.

Ratcliffe NA, Rowley AF, Fitzgerald SW and Rhodes CP. 1985. Invertebrate immunity: basic concepts and recent advances. Int Rev Cytol 97, 183-350. http://dx.doi.org/10.1016/S0074-7696(08)62351-7.

Rodríguez-Ramos T, Espinosa G, Hernández-López J, Gollas-Galván T, Marrero J, Borrell Y, Alonso ME, Bécquer U and Alonso M. 2008.
Effects of Escherichia coli lipopolysaccharides and dissolved ammonia on immune response in southern white shrimp Litopenaeus schmitti. Aquaculture 274, 118-125. http://dx.doi.org/10.1016/j. aquaculture.2007.10.049.

Sotelo-Mundo RR, Islas-Osuna MA, de-la-Re-Vega E, HernándezLópez J, Vargas-Albores F and Yepiz-Plascencia G. 2003. cDNA cloning of the lysozyme of the white shrimp Penaeus vannamei. Fish Shellfish Immunol 15, 325-331. http://dx.doi.org/10.1016/ S1050-4648(02)00176-6.

Sung HH and Sun R. 1999. Intrahaemolytic activity of lysosomal enzymes in Penaeus monodon and Macrobrachium rosenbergii. Fish Shellfish Immunol 9, 505-508.

Supungul P, Klinbunga S, Pichyangkura R, Jitrapakdee S, Hirono I, Aoki T and Tassanakajon A. 2002. Identification of immune-related genes in haemocytes of black tiger shrimp (Penaeus monodon). Mar Biotechnol 4, 487-494. http://dx.doi.org/10.1007/s10126-0020043-8.

Supungul P, Rimphanitchayakit V, Aoki T, Hirono I and Tassanakajon A. 2010. Molecular characterization and expression analysis of a c-type and two novel muramidase-deficient i-type lysozymes from Penaeus monodon. Fish Shellfish Immunol 28, 490-498. http:// dx.doi.org/10.1016/j.fsi.2010.01.003.

Tyagi A, Khushiramani R, Karunasagar I and Karunasagar I. 2007. Antivibrio activity of recombinant lysozyme expressed from black tiger shrimp, Penaeus monodon. Aquaculture 272, 246-253. http:// dx.doi.org/10.1016/j.aquaculture.2007.08.055.

Xue Q, Hellberg ME, Schey KL, Itoh N, Eytan RI, Cooper RK and La Peyre JF. 2010. A new lysozyme from the eastern oyster Crassostrea virginica, and a possible evolutionary pathway for itype lysozymes in bivalves from host defence to digestion. BMC Evol Biol 10, 213. http://dx.doi.org/10.1186/1471-2148-10-213.

Yao CL, Wu CG, Xiang JH, Li F, Wang ZY and Han X. 2008. The lysozyme and lysozyme response in Chinese shrimp Fenneropenaeus chinensis to Vibrio anguillarum and laminarin stimulation. J Exp Mar Biol Ecol 363, 124-129. http://dx.doi.org/10.1016/j.jembe.2008.06.035.

Zasloff M. 2002. Innate immunity, antimicrobial peptides, and protection of the oral cavity. The Lancet 360, 1116-1117. http://dx.doi. org/10.1016/S0140-6736(02)11239-6.

Zhang HW, Sun C, Sun SS, Zhao XF and Wang JX. 2010. Functional analysis of two invertebrate-type lysozymes from red swamp crayfish Procambarus clarkii. Fish Shellfish Immunol 29, 1066-1072. http://dx.doi.org/10.1016/j.fsi.2010.08.023.

Zhao J, Song L, Li C, Zou H, Ni D, Wang W and Xu W. 2007. Molecular cloning of an invertebrate goose-type lysozyme gene from Chlamys farreri, and lytic activity of the recombinant protein. Mol Immunol 44, 1198-1208. http://dx.doi.org/10.1016/j.molimm.2006.06.008 